\title{
The Effect of Event Sponsorship on Customer's Brand Awarness and Purchase Intention-A Case Study of Toyota Vietnam
}

\author{
Mai Ngoc Khuong ${ }^{1} \&$ Ngo Thi Kim Chau ${ }^{1}$ \\ ${ }^{1}$ School of Business, International University, Vietnam National University-HCMC, Ho Chi Minh city, Vietnam \\ Correspondence: Mai Ngoc Khuong, School of Business, International University, Vietnam National \\ University-HCMC, Ho Chi Minh city, Vietnam. E-mail: mnkhuong@hcmiu.edu.vn
}

Received: November 10, 2016

Accepted: November 18, 2016 Online Published: January 21, 2017

doi:10.5539/res.v9n1p148

URL: http://dx.doi.org/10.5539/res.v9n1p148

\begin{abstract}
The purpose of this research was to investigate how event sponsorship directly affected customer's purchase intention and indirectly through the mediation of brand awareness. The quantitative approach was applied with structured questionnaires directly delivered to sports fans of V-league football champion in Binh Duong province, Vietnam. The empirical results showed that attitude and attention towards the sponsorship indirectly affected purchase intention. The fit of the sponsored events and event involvement both directly and indirectly affected customer's purchase intention. In addition, brand recognition played a meaningful mediation role in the relationship between event sponsorship and customer's purchase intention.
\end{abstract}

Keywords: sponsorship, brand awareness, brand recall, brand recognition, consumers' purchase intention

\section{Introduction}

Sponsorship defined as "an investment, in cash or in kind, in an activity, in return for access to the exploitable commercial potential associated with this activity" (Meenaghan, 1991, p. 36). Companies desired to achieve marketing's purpose through sponsorship. The purposes of sponsorship include increasing sales, generating and raising awareness, reaching new target markets, and enhancing corporate image (Shank, 1999). Sports are the aspiration for sponsorship (McCarville, Flood, \& Froats, 1998). Moreover, sports focus on public interest and are the subjects of involvement, commitment, and emotional connection (McDonald, 1991). Additionally, sports can show highly effective images and attract to the almost target group (Ferrand \& Pages, 1996). For above these reasons, marketers decided to increase sports sponsorship as a considerable modification in traditional marketing communications. In 2015, Toyota became the main sponsor of the V. League and the Toyota Mekong Club Championship in order to contribute to the development of Viet Nam's football. Toyota spending on sponsorship reached VND 30 billion at this year. In 2016, Toyota's investment in sponsorship has grown from VND 30 billion in 2015 to VND 40 billion in 2016, which represents a 30 percentage increase over this time period. According to the V. League 2016, it will kick off on 20 February nationwide with 14 clubs competing in 182 matches through 26 rounds and the winner will receive VND 3 billion (USD 133,000) while the runners-up pocket half that amount.

Toyota has spent a huge amount of money on sports sponsorship. To be precise, they used more than VND 40 billion to organize VPF and prizes for winners, which is a huge investment for marketing at V-League. Moreover, as commercial sponsorship is a form of marketing communication, it is necessary to explore how it actually influences consumers and their perception and behaviors of commercial sponsorship as well as sponsor's products instead of simply measuring the sales or reach the performance of the brand. In essence, the effectiveness of Toyota's sports sponsorship program in terms of customers' response from a variety of perspectives in the Vietnamese market is necessary to be investigated because Toyota's expenditures on sponsorship are increasing. Therefore, the research will discover which factors between sponsor and event have strongly effect on purchase intention in order to help advertisers give an effective marketing strategy for the sponsors' products in the Vietnamese market. The main of the purpose of this study points out that the factors have a positive effect on brand awareness to improve opportunity toward the purchase of Toyota's products in Binh Duong province. For more detail, the objectives of the research find the problem as follow: What is the effect of event sponsorship on customer's brand awareness and purchase intention. Specifically, this study was designed to examine the influence of several factors on the purchase to a sponsor's products in terms of attitude 
toward the sponsor, attention to sponsor's promotion, sponsor event fit, event involvement and the mediating role of brand awareness.

\section{Literature Review}

\subsection{Purchase Intention}

Purchase intention can be defined as "if a certain company supported a particular event then it would improve the chances that a consumer would buy the sponsor's products" (Speed \& Thompson, 2000). It is likely that the customers intend to purchase or consume the sponsor's product in the future, which is an effect of the sponsorship. Smith (2008) had gone deeper into the measures of purchase focusing on the direct effect of sponsorship on sales. The positive attitude approach to the product has also been determined to be a primary of purchase intention. Whitlark, Geurts, and Swenson (1993) discovered that " $75 \%$ of the respondents who indicated that they would be likely to buy a sponsor's products actually did purchase the products within three to six months". Additionally, Pitts (2004) showed that "a staggering 92\% of respondents at Gay Games IV who said that they were more likely to purchase the sponsors' products because of the companies' support for the event". Yong Jae et al. (2008) also illustrates that the future purchase intention of consumers can be examined in sponsorship. This leads practically the purpose of sponsored company (Howard \& Crompton, 1995, p. 363) because of the aim of purchase is a sign of great worth and advantage as an influence future sales on sponsorship.

\subsection{Brand Awareness}

Aaker (1996) defined "the ability of a consumer can recognize and recall a brand in different situations". Brand awareness consists of brand recall and brand recognition. In the sponsorship context, brand recognition examines if the ability of consumer recognize a particular sponsor appearing in a football match, given the brand name as a cue. Brand recall connected to the ability of consumer recover a particular sponsor from memory given only the product category as a cue or by even solely asking for any sponsor that comes to mind (Keller, 1993). Further, Hoeffler and Keller (2002) showed that brand awareness can differentiate from depth and width. Depth explained "how to make consumers to recall or identify brand easily" and width concluded, "when consumers purchase a product, a brand name will come to their minds at once". Whether a product is in possession of brand depth and width at the same time, consumers will consider a particular brand at the time of purchasing a product which results higher brand awareness to that product. Additionally, brand name is the main component of brand awareness (Davis, Golicic, \& Marquardt, 2008). As a result, brand awareness will have an influence on purchase decision by way of brand association, and when a product possesses favorable brand image, it will support to marketing activities (Keller, 1993). Brand awareness has a great effect on purchase intention due to the tendency of the customer to purchase a familiar and well-known product (Keller, 1993; Macdonald \& Sharp, 2000). Brand awareness can assist consumers in order to recognize a brand from a product category and make a purchase decision (Percy \& Rossiter, 1992). In addition, brand awareness has a great impact on choice and can have previously regarded as a product category (Hoyer \& Brown, 1990). Furthermore, brand awareness plays a role as a crucial element to the consumer purchase intention, and specific brands will be gathered to consumers' mind-affecting consumer purchase decision. Moreover, when consumers recognize the familiar brand, it leads to a higher purchase intention. In others words, a product has higher brand awareness that results in higher market share and the act of evaluating for better quality.

\subsection{Attitude toward the Sponsor}

Prior sponsorship research pointed out that attitude toward the sponsor was the most appropriate factors to use in examining the effectiveness of sponsorship (Javalgi et al., 1994; Stipp \& Schiavone, 1996). One of the main purposes sponsors is that customers are positive about attitudes toward the sponsor in the relationship between sponsor and sponsored event (Cornwell \& Maignan, 1998). In addition, Speed and Thompson (2000) had pointed out that the influence of a company on person's attitude in the direction of company financially assisted to a specific event. This research had shown that sponsors who possess positive image get an approving response to their sponsorships as compared to those not to be able to afford.

\subsection{Attention to Sponsor's Promotion}

Recent research has explored that "advertising response used cognitive psychology to suggest that the mere-exposure effect can lead to higher evaluation of a product when advertising responses are automatic and unconscious. And the consumers' attitude toward different attributes of a promotion play a major role in shaping their response to that promotions" (Grunert, 1996). Speed and Thompson (2000) indicated that "customers believe sponsorship of a particular event by a particular sponsor will affect their attention to the sponsor and 
remember the sponsor's promotion". This means that the attention to sponsor's promotion had built up a practice in customers' consideration through sponsored event. When watching sponsored event can improve customers' concentration about the sponsorship that they notice the sponsor's name on sports event and pay attention to the advertisement of the sponsor.

\subsection{Sponsor-Event Fit}

As the result of researches, fit between the sponsor and the sponsored event is attached very great importance to endorsement literature (Crimmins \& Horn, 1996; Meenaghan \& Shipley, 1999; Speed \& Thompson, 2000). Speed and Thompson (2000, p. 230) have discovered that "the degree to which the pairing of an event and sponsor is perceived as well matched or a good fit, without any restriction on the basis used to establish fit". A fit between sponsor and event can be established with the dimensions includes: "sponsor product relevance to the object", "functional similarities" (i.e., sponsor's product and the object are both high quality) and "image/symbolic similarities" (Gwinner, 1997; Rifon et al., 2004; Speed \& Thompson, 2000). Moreover, Martensen et al. (2007) discovered that fit is used as a distinction between positive and negative emotions toward a sponsored event and higher fit that may lead to positive emotions or lower fit that may contribute to negative emotions. In addition, Becker-Olsen and Simmons (2002) defined endorsers as "Good fit between sponsor and object resulted in higher attitudes toward the sponsorship and sponsor. The explanation for a bad-fitting sponsorship created positive effects similar to those for native good fit, with even higher sponsor recall". Their study points out that having the matching good fit with the key measurement for value transfers between event and sponsor to gauge the successful brand awareness.

\subsection{Event Involvement}

Event involvement is defined as "a kind of genuine excitement caused by a strong and solid interest in a specific activity (on our case the sponsored sports event) which results from the importance of this activity for an individual" (Lardinoit \& Derbaix, 2001). Within the context of sponsorship, Meenaghan (2001) had published the idea of fan involvement and state of being involved in the sponsorships. As the result of researches, he investigated focus group that people showed positive emotions regarding the investments of the sponsors because of the increase in event or fan involvement for specific sponsored activity. Additionally, favorably involved fans had knowledge of the sponsor's investments. Hansen and Scotwin (1995) had demonstrated that "sports fans have significantly higher recall than those not involved for one sponsor". In other study from Pham (1992) had concluded as consumer highly involved in a sponsored event, the knowledge of consumer had a strong influence in increasing interest, considerable motivation on the sponsorship and brought about the benefit of sponsor (Crimmins \& Horn, 1996). It is probable that consumer highly connected with sponsored event and strongly endorse to the sponsor. Therefore, respondents who perceived the event to be attractive and interesting believe it would have favorable image towards sponsor (D' Astous \& Bitz, 1995), and this research had a conclusion "sponsors can increase the response to their sponsorship if they select events that are well liked by their target market".

In order to confirm the direct and indirect effects on customer purchase intention this study hypothesized that:

$\mathrm{H}_{1}$ : Factors of event sponsorship positively affect brand recognition.

$\mathrm{H}_{2}$ : Factors of event sponsorship positively affect brand recall.

$\mathrm{H}_{3}$ : Factors of event sponsorship, brand recall, and brand recognition positively affect customer's purchase intention.

$\mathrm{H}_{4}$ : Brand recall mediates the relationships between factors of event sponsorship and customer's purchase intention.

$\mathrm{H}_{5}$ : Brand recognition mediates the relationships between factors of event sponsorship and customer's purchase intention.

\section{Methodology}

\subsection{Questionnaire Design and Data Collection}

The research used Likert Scaling to measure customer's brand awareness and purchase intention with a series of short statements on a given in the surveys in from of the five-point range of responses from 1 (strongly disagree) up to 5 (strongly agree). Attitude toward the sponsor, attention to sponsor's promotion, sponsor-event fit and event involvement was adapted from Speed and Thompson (2000). Brand recognition scale was adjusted from Keller (1993), Aeker (1991) and Yoo, Donthu (2001), brand recall scale from Keller (1993), Aeker (1991) and Rajh (2002) and purchase intention from Boulding, Kalra, Staeling, and Zeithaml (1993), Ajzen and Fishbein 
(1980), Spears and Singh (2004) and Pelsmacker (1998).

For the purpose of this research, there were two important aspects of the sponsor's sports event: the effect of event sponsorship on customer's brand awareness and the influence of them on purchase intention. The study collected primary data in form of questionnaire translated into appropriate Vietnamese version. In Binh Duong Province context, surveys were delivered directly to the respondents that are customers of Toyota and sports fans with V-league football champion. Surveys were collected from 264 respondents among which 37 questionnaires were rejected and remained 227 valuable questionnaires to analyze in this research. Factor analysis and multiple regression were conducted by using SPSS software (version 20).

\subsection{Factor Analysis and Reliability}

Principal component analysis was used with varimax rotation method to investigate meaningful factors from the proposed model. The four independent variables resulted in three factors as in Table 1. Attitude toward the sponsor and attention to sponsor's promotion were grouped into one factor. Therefore, it was reasonably named "attitude and attention towards the sponsorship", including three items of attitude and three items of attention. The second factor was fit of the sponsored events that only remained four items for the following step because one item of the fit variable was eliminated. The final factor was event involvement consisting of four items. Total variance explained of all factors was 73.7 percent and Eigenvalue of each dependent factor was above 1 . KMO was .922 and Barlett's test of sphericity reached its significant value $(\mathrm{p}=.000)$ so this result is considered as satisfactory. Cronbach Alpha values for the three factors were all greater than .70 (Nunnally, 1978), showing high reliability. Thus, the three factors were significant consistency and reliability for further analysis.

Table 1. Summary of independent variables with reliability coefficients

\begin{tabular}{lcc}
\hline \multicolumn{1}{c}{ Given names } & Number of Items & Alpha \\
\hline Attitude and Attention towards the Sponsorship (ATINATE) & 6 & .898 \\
Fit of the Sponsored Events (FITOSEVE) & 4 & .889 \\
Event Involvement (EVINVOL) & 4 & .907 \\
\hline
\end{tabular}

Similarly, Table 2 showed the factor analysis of the group of dependent variables. The mediator Brand Recognition, Brand Recall and dependent variable Purchase Intention were three valuable factors with total variance explained of 73.22 percent and Eigenvalue of each dependent factors all was above 1. KMO value was .892 and significant Barlett's test of sphericity value was $p=.000$. Cronbach Alpha values for the three factors all were greater than 0.7 (Nunnally, 1978). Therefore, the three scales were reliable and considered to remain for subsequent analysis.

Table 2. Summary of dependent variables with reliability coefficients

\begin{tabular}{lcc}
\hline \multicolumn{1}{c}{ Given names } & Number of Items & Alpha \\
\hline Purchase Intention (PURINTE) & 4 & .882 \\
Brand Recognition (BRANRECO) & 5 & .907 \\
Brand Recall (BRANRECA) & 4 & .849 \\
\hline
\end{tabular}

\section{Research Findings}

\subsection{Characteristics of Respondents}

Total 264 questionnaires were received but the usable sample size was $227 ; 71.4 \%$ were male and $28.6 \%$ were female. This is a representative total number of respondents the following football in V-League. Football has traditionally regarded as a "male" sport, but lately women have begun to present an involvement in it. As a shown in Table 3, there is a greater percentage of marriage than single status in the population. As far as the age distribution is concerned, there are five different sized categories: $4.4 \%$ were over than 55 years old, $11.5 \%$ were between 45 and 55 years old and $9.3 \%$ were between 18 and 25 years old. The majority of respondents are between 25 and 35 years old, $42.7 \%$, respectively and 32.2 percent between 35 and 45 years old. Almost 
respondents have an experience in the workplace at the time, which was equal to the minimum one-year seniority. Besides, they earned approximately VND 15 millions.

Table 3. The summary of demographic information of respondent $(\mathrm{N}=227)$

\begin{tabular}{|c|c|c|c|}
\hline & & Frequency & Percentage \\
\hline \multirow{2}{*}{ Gender } & Male & 162 & 71.4 \\
\hline & Female & 65 & 28.6 \\
\hline \multirow{4}{*}{ Marital Status } & Single & 69 & 30.4 \\
\hline & Married & 158 & 69.6 \\
\hline & $18-25$ & 21 & 9.3 \\
\hline & $25-35$ & 97 & 42.7 \\
\hline \multirow[t]{5}{*}{ Age } & $35-45$ & 73 & 32.2 \\
\hline & $45-55$ & 26 & 11.5 \\
\hline & Over 55 & 10 & 4.4 \\
\hline & Less than 1 year & 3 & 1.3 \\
\hline & $1-4$ years & 43 & 18.9 \\
\hline \multirow[t]{5}{*}{ Seniority } & 4-7 years & 66 & 29.1 \\
\hline & $7-10$ years & 40 & 17.6 \\
\hline & Over 10 years & 75 & 33.0 \\
\hline & Less than VND 15 millions & 108 & 47.6 \\
\hline & VND 15-20 millions & 62 & 27.3 \\
\hline \multirow[t]{3}{*}{ Income } & VND 20-25 millions & 25 & 11.0 \\
\hline & VND 25-30 millions & 8 & 3.5 \\
\hline & Over VND 30 millions & 24 & 10.6 \\
\hline
\end{tabular}

\subsection{Relationship between Independent Variables, BRARECA, BRARECO and Purchase Intention}

Table 4 showed the results of the Pearson's Correlation coefficient which is a statistical measure of the strength and direction of association that exist between factors of event sponsorship, brand recall, brand recognition and customer's purchase intention. The finding indicated the positive correlations between five independent variables (ATINATE, FITOSEVE, EVINVOL, BRARECA and BRARECO) and the dependent variable (PURINTE) at $\mathrm{p}<.001$. All variables were positively correlated with PURINTE. Among these relationships, the strongest was a correlation between FITOSEVE and PURINTE $(\mathrm{r}=.666, \mathrm{p}<.001)$, however, the weakest was a correlation between BRARECA and PURINTE $(\mathrm{r}=.431, \mathrm{p}<.001)$. In other words, the high level of factors of event sponsorship, brand recall and brand recognition were associated with the high level of Consumers' Purchase Intention.

Table 4. Correlations between variables

\begin{tabular}{lccccc}
\hline & PURINTE & $\mathbf{1}$ & $\mathbf{2}$ & $\mathbf{3}$ & $\mathbf{4}$ \\
\hline 1. ATINATE & $.561^{*}$ & 1.000 & & & \\
2. FITOSEVE & $.666^{*}$ & $.725^{*}$ & 1.000 & & \\
3. EVINVOL & $.635^{*}$ & $.640^{*}$ & $.667^{*}$ & 1.000 & $.591^{*}$ \\
4. BRANRECO & $.628^{*}$ & $.639^{*}$ & $.659^{*}$ & .000 \\
5. BRANRECA & $.431^{*}$ & $.547^{*}$ & $.512^{*}$ & $.524^{*}$ & $.629^{*}$ \\
Mean & 3.54 & 3.79 & 3.63 & 3.67 & 3.84 \\
STD & .842 & .790 & .818 & .898 & .749 \\
\hline
\end{tabular}

Note. * Significant level at $p<.001$. 


\subsection{Direct Effects on the Mediator Brand Recognition and Brand Recall}

Brand recognition was significantly affected by three factors: attitude and attention towards the sponsorship $(\mathrm{B}=.261)$, fit of the sponsored events $(\mathrm{B}=.301)$, event involvement $(\mathrm{B}=.163)$. This implies that the participants are the strong supporter of the $\mathrm{V}$-League and feel more favorable emotions toward Toyota. Additionally, there is a logical connection between V-League and Toyota so sponsorship makes the audiences more likely to remember Toyota's promotion.

Brand recall was strongly influenced by two factors: attitude and attention towards the sponsorship $(\mathrm{B}=.256)$ and event involvement $(B=.192)$. Conversely, the interaction between fit and brand recall showed no significant contribution. This study suggested that as a high level of attitude and attention towards the sponsorship and event involvement becomes apparent, the brand recall is likely to be greater.

\subsection{Direct Effects on Customer Purchase Intention}

Among the three factors, attitude and attention towards the sponsorship and event involvement $(\mathrm{B}=.330$ and $\mathrm{B}=.268$, respectively) had direct effects to customer purchase intention. It illustrated that the target audiences are favorable and positive attitudes in the relationship between sponsor and sponsored event and pay attention to the Toyota's advertising during the V-League football match. Conversely, fit of the sponsored events also did not exert significant influence on customer purchase intention.

Moreover, brand recognition had a positive effect on purchase intention $(\mathrm{B}=.327)$ with high impact. However, brand recall showed no significant effect on purchase intention. It is implied that the audiences are merely able to recognize a specific Toyota sponsor through Toyota's brand name occurring the logo of V-League and Toyota's Banner Advertising.

\subsection{Indirect Effects on Customer Purchase Intention}

The outcomes of regression analysis revealed there were three independent variables that impact on PURINTE through BRARECO. The indirect effect of the independent variable on the dependent variable through the mediator was the total result of the independent variable on the mediator and the mediator on the dependent variable (Preacher \& Hayes, 2008). Brand recognition was significantly affected by three factors: attitude and attention towards the sponsorship $(\mathrm{B}=.412)$, fit of the sponsored events $(\mathrm{B}=.301)$ and event involvement $(\mathrm{B}=.226)$. Then, brand recognition $(\mathrm{B}=.327)$ was significantly accounted for purchase intention. Consequently, through the intervening variable of brand recognition, the factor of FITOSEVE, ATINATE and EVINVOL affected indirectly on PURINTE .098, .086 and .053 at respectively.

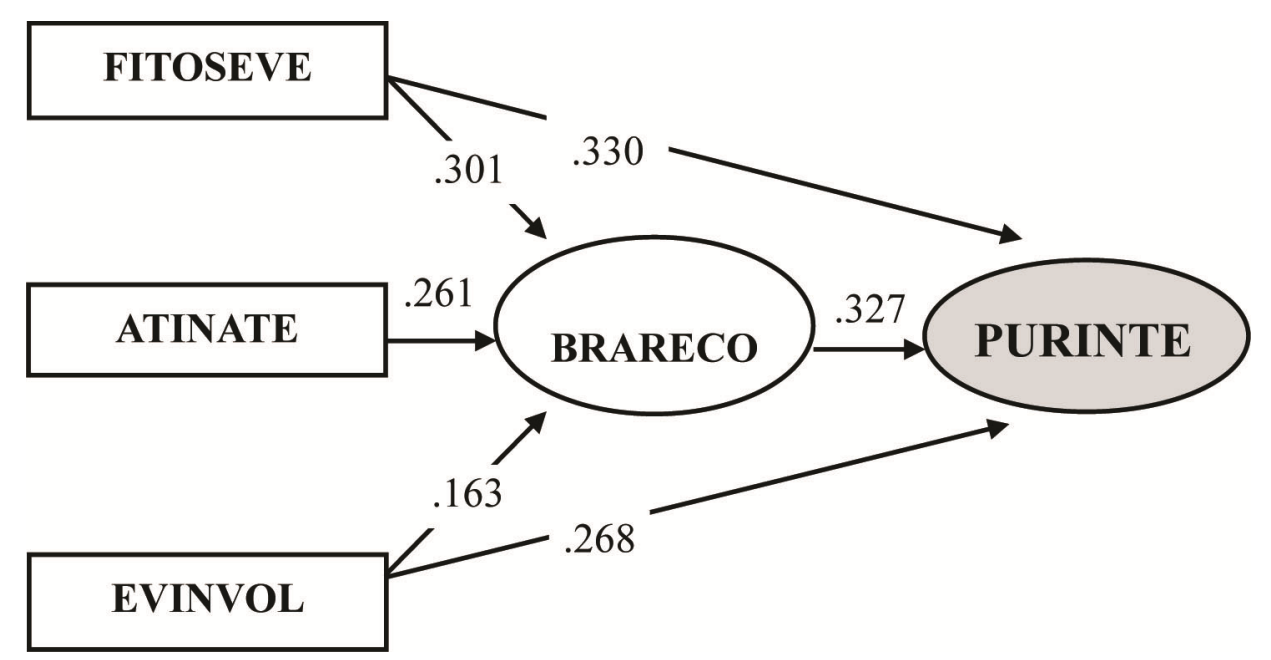

Figure 1. Path coefficients of hypothesis testing 


\subsection{Significant of the Indirect Effect}

According to Preacher and Hayes (2008), the bootstrapping method was used to test the significance of indirect effects or mediation. If there is a zero fell within the interval range between the lower (LLCI) and upper boundary (ULCI) in order that there is no mediation or indirect effect at 95 percent confidence. On the other hand, if zero does not happen between the LLCI and the ULCI in order that the mediation or indirect effect is significant with 95 percent confidence. As can be seen in the outcomes of Table 5, the indirect effects of ATINATE, FITOSEVE and EVINVOL on PURINTE through the mediation of BRARECO were estimated to be placed between .0396 (LL) and .1387 (UL); .0486 (LL) and .1553 (UL); .0203 (LL) and .0933 (UL) with 95 percent confidence, respectively. Because the range between lower and upper boundary did not contain zero at the 95 percent confidence interval, we can conclude that the indirect effects of ATINATE, FITOSEVE and EVINVOL on PURINTE were significantly different from zero at $\mathrm{p}<.05$ (two tailed) and the mediation of BRARECO in this research was correct.

\subsection{Total Causal Effect of the Customer Purchase Intention}

As can be seen, the output of Table 5 was divided up into two groups of direct and indirect effects on PURINTE through BRARECO. The total effect of FITOSEVE had the strongest positive impact on PURINTE $(\mathrm{B}=.428)$. Besides, positive effects on PURINTE are ATINATE $(\mathrm{B}=.086)$, EVINVOL $(\mathrm{B}=.321)$ and BRARECO $(\mathrm{B}=.327)$. To sum up, the total effects of independent variables impact Consumers' Purchase Intention are 1.162 including $79.6 \%$ of direct effects from FITOSEVE, EVINVOL and BRARECO and $20.4 \%$ of indirect effects from ATINATE, FITOSEVE and EVINVOL.

Table 5. Direct, indirect and total causal effects

\begin{tabular}{cccccc}
\hline \multirow{2}{*}{ Variables } & \multicolumn{3}{c}{ Casual effects } & LL & UL \\
\cline { 2 - 4 } & Direct & Indirect & Total & & .0396 \\
\hline ATINATE & ---- & .086 & .086 & .0486 & .1387 \\
FITOSEVE & .330 & .098 & .428 & .0203 & .0933 \\
EVINVOL & .268 & .053 & .321 & & \\
BRARECO & .327 & ---- & .327 & \\
Total & $\mathbf{. 9 2 5}$ & $\mathbf{. 2 3 7}$ & $\mathbf{1 . 1 6 2}$ & \\
\hline
\end{tabular}

\section{Discussion and Conclusion}

The purpose of this research was to examine empirically the link between brand awareness, specifically, brand recognition and purchase intention in sports sponsorship in Vietnam. The finding showed that in the line with prior empirical researches (Chi et al., 2009; Shahbaz et al., 2010) brand recognition has a significantly positive relationship with purchase intention. On the other hand, brand recall has no significant impact on purchase intention. Brand recognition is the main component in sponsorship context because sponsor's brand certainly becomes a customer purchase decision. In other words, if customers are not aware of the specific sponsor when they search for the exact sponsor's product, then it is very unlikely for them to choose another brand. Thus, brand managers provide guidance to their brand marketing communication strategy to assist in maintaining customer recognition and finding a new solution to improve customers' brand recall compared with its competitors.

The findings of this research also confirmed the significantly positive relationship between three important variables consisting of attitude and attention towards the sponsorship, fit of the sponsored events and event involvement and brand recognition. Attitude and attention toward the sponsorship is tested to have the strongest direct effect on brand recognition. In addition, fit of the sponsored is of major importance in affecting the effectiveness of a sponsorship (Erik \& Hans, 2011) and higher fit between the image of the sponsor and sponsored event contributing to favorable emotions. This shows that marketers in Toyota invested successfully an enormous amount of money in becoming the primary sponsor for V-League football champion because the respondents are favorable about attitudes toward the sponsor in the relationship between sponsor and sponsored event (Cornwell \& Maignan, 1998). Besides, Toyota displayed successfully the logo and brand name that immediately come into the view of audiences to attract attention, enjoy following coverage of the V-League and recognize the sponsors' brand in V-League football. 
Furthermore, the study verifies that brand recognition acts as a mediator among three factors including attitude and attention towards the sponsorship, fit of the sponsored events and event involvement and purchase intention. The research also finds that if consumers can recognize a particular sponsor appearing in a football match, given the brand name as a cue (Keller, 1993) when they want to buy a sponsor's product, it means that Toyota car holds higher brand recognize through sponsorship to the certain sport event. When the brand name of sponsor recognize easily famous event, it can gain consumers' preferences, create positive emotions toward sponsor in other to pay attention to other advertising or campaign and increase their purchase intention.

Finally, the outcomes of this study revealed that in line with the study of Speed, Richard and Peter Thompson (2000), attitude and attention towards the sponsorship and event involvement have a direct influence on customer purchase intention. Event involvement is positively associated with purchase intention to sponsorship because almost respondents are as sports fans that highly involved in a sponsored event and their knowledge that have a strong effect on increasing interest from the investment of sponsor (Crimmins \& Horn, 1996). The results of this study also indicated the direct link between attitude towards the sponsors' product and Customers' purchase intention. This was related to the research by (MacKenzie, Lutz, \& Belch, 1986; Madrigal, 2001) in the sponsorship context. When a consumer has a favorable attitude and their belief toward a sponsor, they show the strongest inclination to know and regard a particular sponsor product. This leads to the behavioral intentions as consumer purchase decisions from the effect of positive individual's attitude.

\section{Recommendations for Future Research}

This study concentrates on the respondents in Binh Duong Province. It is considered the representation of small sample size in Viet Nam that results in the problem to consider the whole country. There is the limitation of the sample in this research so future studies should investigate the larger sample of the population and the extension of other major cities and provinces, such as Hanoi, Hue, Danang, Can tho. These places could have potential respondents both seeing the V-League football match and demanding to buy sponsors' products. It is suggested that future research can expand participants to carry out a survey and become general consumers. Moreover, the outcome of research is believed to help extend the understanding of how to affect consumer's purchase intention through sponsorship method in order to improve marketing position and increase achieve the business turnover.

The finding finds out three factors consisting of attitude and attention towards the sponsorship, fit of the sponsored events and event involvement have both the direct and indirect effect on brand awareness to improve opportunity toward the purchase of Toyota's products. Thus, further research should base on the result of this study in order to discover other variables influencing on brand awareness and purchase intention in the relationship between Toyota and V-League football. Because this research may not review the effects of all factors of sponsorship on customer's purchase intention through the mediate of brand recognize. Besides, future research is possible to discover the source of information and spend time on review much relative literature in sports sponsorship to increase the greater valuable of research result.

\section{References}

Aaker, D. A. (1991). Managing brand equity: Capitalizing on the value of a brand name. New York: Free Press.

Aaker, D. A. (1996). Measuring brand equity across products and markets. California Management Review, 38(3), 102-120. https://doi.org/10.2307/41165845

Ajzen, I., \& Fishbein, M. (1980). Understanding attitudes and predicting social behavior. Englewood Cliffs, NJ: Prentice-Hall.

Becker-Olsen, K., \& Carolyn, J. S. (2002). When Do Social Sponsorships Enhance or Dilute Equity? Fit, Message Source, and the Persistence of Effects. Consumer Research, 29, 287-288.

Boulding, W., Ajay, K., Richard, S., \& Valarie, A. Z. (1993). A Dynamic Process Model of Service Quality: From Expectations to Behavioral Intentions. Journal of Marketing Research, 30(February), 7-27. https://doi.org/10.2307/3172510

Chi, H. K., Huery, R. Y., \& Ya, T. Y. (2009). The Impact of Brand Awareness on Consumer Purchase Intention: The Mediating Effect of Perceived Quality and Brand Loyalty. The Journal of International Management Studies, 4(1), 2009.

Cornwell, \& Isabelle, M. (1998). An International Review of Sponsorship Research. Journal of Advertising, 27(1), 1-21. https://doi.org/10.1080/00913367.1998.10673539

Crimmins, J., \& Horn, M. (1996). Sponsorship: From management ego trip to marketing success. Journal of Advertising Research, 36(4), 11-21. 
D’Astous, A., \& Pierre, B. (1995). Consumer Evaluations of Sponsorship Programmes. European Journal of Marketing, 29(12), 6-22. https://doi.org/10.1108/03090569510102504

Davis, D. F., Golicic, S. L., \& Marquardt, A. J. (2008). Branding a B2B service: Does a brand differentiate a logistics service provider? Industrial Marketing Management, 37, 218-227. https://doi.org/10.1016/j.indmarman.2007.02.003

De Pelsmacker, P. D. (1998). Advertising characteristics and the attitude towards the ad-A study of 100 likeable TV commercials. Marketing and Research Today, 27(4), 166-179.

Ferrand, A., \& Pages, M. (1996). Image sponsoring: A methodology to match event and sponsor. Journal of Sport Management, 1(3), 278-291. https://doi.org/10.1123/jsm.10.3.278

Grunert, \& Klaus, G. (1996). Automatic and Strategic Processes in Advertising Effects. Journal of Marketing, 60(4), 88-101. https://doi.org/10.2307/1251903

Gwinner, \& Kevin, P. (1997). A Model of Image Creation and Image Transfer in Event Sponsorship. International Marketing Review, 14(3), 145-158. https://doi.org/10.1108/02651339710170221

Hansen, F., \& Scotwin, L. (1995). An Experimental Enquiry into Sponsoring: What Effects can be Measured? Marketing and Research Today, 173-181.

Hoeffler, S., \& Keller, K. L. (2002). Building brand equity through corporate societal marketing. Journal of Public Policy \& Marketing, 21(1), 78-89. https://doi.org/10.1509/jppm.21.1.78.17600

Howard, D. R., \& Crompton, J. L. (1995). Financing Sport. Morgantown. WV: Fitness Information technology, Inc.

Hoyer, W. D., \& Brown, S. P. (1990). Effects of brand awareness on choice for a common repeat-purchase product. Journal of Consumer Research, 17(2), 141-148. https://doi.org/10.1086/208544

Javalgi, R. G., Mark, B. T., Andrew, C. G., \& Edward, L. (1994). Awareness of Sponsorship and Corporate Image: An Empirical Investigation. Journal of Advertising, 23(4), 47-58. https://doi.org/10.1080/00913367.1943.10673458

Keller, K. L. (1993). Conceptualizing, measuring, and managing customer-based brand equity. Journal of Marketing, 57(1), 1-22. https://doi.org/10.2307/1252054

Lardinoit, T., \& Derbaix, C. (2001). Sponsorship and Recall of Sponsors. Psychology \& Marketing, 18, 167-190. https://doi.org/10.1002/1520-6793(200102)18:2<167::AID-MAR1004>3.0.CO;2-I

Macdonald, E. K., \& Sharp, B. M. (2000). Brand awareness effects on consumer decision making for a common, repeat purchase product: A replication. Journal of Business Research, 48, 5-15. https://doi.org/10.1016/S0148-2963(98)00070-8

MacKenzie, S. B., Lutz, R. J., \& Belch, G. E. (1986). The Role of Attitude toward the Ad as a Mediator of Advertising Effectiveness: A Test of Competing Explanations. Journal of Marketing Research, 23(May), 130-143. https://doi.org/10.2307/3151660

Madrigal, R. (2001). Social Identity Effects in a Belief-Attitude-Intentions Hierarchy: Implications for Corporate $\begin{array}{llllll}\text { Sponsorship. } & \text { Psychology } \quad \& \quad \text { Marketing, } & 18(2), & 145-165 .\end{array}$ https://doi.org/10.1002/1520-6793(200102)18:2<145::AID-MAR1003>3.0.CO;2-T

Martensen, A. L. G., Lars, B., \& Martin, J. (2007). Application of a Model for the Effectiveness of Event Marketing. Journal of Advertising Research, 47(September), 283-301. https://doi.org/10.2501/S0021849907070316

McCarville, R. E., Flood, C. M., \& Froats, T. A. (1998). The effectiveness of selected promotions on spectators' assessments of a nonprofit sporting event sponsor. Journal of Sport Management, 12, 51-62. https://doi.org/10.1123/jsm.12.1.51

McDonald, C. (1991). Sponsorship and the image of the sponsor. European Journal of Marketing, 25, 31-38. https://doi.org/10.1108/EUM0000000000630

Meenaghan, T. (2001). Understanding sponsorship effects. Psychology \& Marketing, 18(2), 95-122. https://doi.org/10.1002/1520-6793(200102)18:2<95::AID-MAR1001>3.0.CO;2-H

Meenaghan, T., \& Shipley, D. (1999). Media effect in commercial sponsorship. European Journal of Marketing, 33(3/4), 328-347. https://doi.org/10.1108/03090569910253170 
Meenaghan, T. (1991). The Role of Sponsorship in the marketing Communication mix. International Journal of Adverstising, 10(1), 35-47.

Nunnally, J. C. (1978). Psychometric Theory. McGraw-Hill, New York, NY.

Olson, E. L., \& Hans, M. T. (2011). Explaining and Articulating the Fit Construct in Sponsorship. Journal of Advertising, 40(1), 57-70. https://doi.org/10.2753/JOA0091-3367400104

Percy, L., \& Rossiter, J. R. (1992). A model of brand awareness and brand attitude advertising strategies. Psychology \& Marketing, 9, 263-274. https://doi.org/10.1002/mar.4220090402

Pham, T. M. (1992). Effects of involvement, arousal and pleasure on the recognition of sponsorship stimuli. Advances in Consumer Research, 19, 85-93.

Pitts, B. G., \& Slattery, J. (2004). An examination of the effects of time on sponsorship awareness levels. Sport Marketing Quarterly, 13(1), 43-54.

Preacher, J. K., \& Hayes, A. F. (2008). Asymptotic and resampling strategies for assessing and comparing indirect effects in multiple mediator models. Behavior Research Methods, 40(3), 879-891. https://doi.org/10.3758/BRM.40.3.879

Rajh, E. (2002). Development of a scale for measuring customer-based brand equity. EKONOMSKI PREGLED, $53(7-8), 770-781$.

Rifon, N. J., Sejung, M. C., Carrie S. T., \& Hairong, L. (2004). Congruence Effects in Sponsorship. Journal of Advertising, 33(1), 29-42. https://doi.org/10.1080/00913367.2004.10639151

Shahbaz, S., Hans, R. K., Israr, A., \& Imran, M. Q. (2010, June). Cause related marketing campaigns and consumer purchase intentions: The mediating role of brand awareness and corporate image. African Journal of Business Management, 4(6), 1229-1235.

Shark, M. D. (1999). Sports Marketing—A Strategic Perspective. Upper Saddle River: Prentice-Hall Inc.

Smith, A., Graetz, B., \& Westerbeek. H. (2008). Sports sponsorship, team support and purchase intentions. Journal of SportsMarketing Communications, 14(5), 387-404. https://doi.org/10.1080/13527260701852557

Spears, N., \& Singh, S. N. (2004). Measuring attitude toward the brand and purchase intentions. Journal of Current Issues and Research in Advertising, 26(2), 53-66. https://doi.org/10.1080/10641734.2004.10505164

Speed, R., \& Peter, T. (2000). Determinants of Sports Sponsorship Response. Journal of the Academy of Marketing Science, 28(2), 226-238. https://doi.org/10.1177/0092070300282004

Stipp, H., \& Nicholas, P. S. (1996). Modeling the Impact of Olympic Sponsorship on Corporate Image. Journal of Advertising Research, 36(4), 22-28.

Whitlark, D. B., Geurts, M. D., \& Swenson, M. J. (1993). New product forecasting with a purchase intention survey. Journal of Business Forecasting, Fall, 18-21.

Yong, J. K., Kyoungtae, K., Cathryn, L. C., \& Tae, H. K. (2008). The Effects of Sport Involvement, Sponsor Awareness and Corporate Image on Intention to Purchase Sponsor's Products. International Journal of Sport Marketing \& Sponsorship, 1 .

Yoo, B., \& Donthu, N. (2001). Developing and validating a multidimensional consumer-based brand equity scale. Journal of Business Research, 52(1), 1-14. https://doi.org/10.1016/S0148-2963(99)00098-3

\section{Copyrights}

Copyright for this article is retained by the author(s), with first publication rights granted to the journal.

This is an open-access article distributed under the terms and conditions of the Creative Commons Attribution license (http://creativecommons.org/licenses/by/4.0/). 